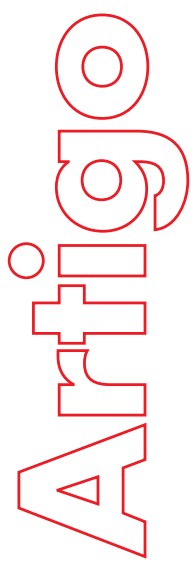

revista

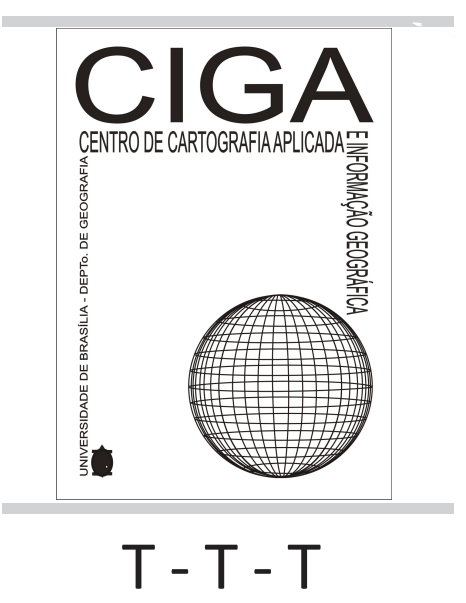

Revista Eletrônica:

Tempo - Técnica - Território,

V.5, N.2 (2014), 23:40

ISSN : $2177-4366$

DOI: https://

doi.org/10.26512/

ciga.v5i2.15399

\section{CURRICULUM, ASSESSMENT AND GEOGRAPHY SCHOOL}

\author{
Lineu Aparecido Paz e Silva
}

p. $23-40$

Como citar este artigo:

SILVA, L. A. P. CURRICULUM, ASSESSMENT AND GEOGRAPHY SCHOOL. Eletronic Magazine: Time - Techinique - Territorry, v.5, n.2 (2014), p. 23:40 ISSN: 2177-4366.

DOI: https://doi.org/10.26512/ciga.v5i2.15399

Available in: http://periodicos.unb.br/index.php/ciga/

Este obra está licenciado com uma Licença Crea tive Commons

Atribuição-NãoComer cial 4.0 Inter nacional. 


\title{
CURRICULUM, ASSESSMENT AND GEOGRAPHY SCHOOL
}

\author{
Lineu Aparecido Paz e Silva \\ Licenciado em Geografia Pela Universidade Estadual do Piauí-UESPI \\ Mestrando em Geografia pela Universidade Federal do Piauí-UFPI \\ Professor de Geografia da educação básica \\ lineuprofgeo@hotmail.com
}

\begin{abstract}
This paper presents the objective to discuss curriculum, rating, school geography and its developments in basic education and the relationship of the current curriculum practice with the systematic review of the existing educational institutions with developments in the teaching- learning process . For this study, a literature study was conducted on some of the major topic related to curriculum , assessment and school geography works . The basis for the development of this study were the main authors portray in detail the main features of curriculum and assessment, in particular Maria Martins Adailza Albuquerque, Tomaz Tadeu da Silva , and Antonio Flavio Barbosa Moreira involving discussions of current curricular practice and the relationship of this with the assessment in the teaching of geography .. It is in schools that experience the curriculum in fact, and the school environment is the place that develops a curriculum pedagogy that feature content of character generally directed to an instructional design or even politics. The relationship of the curriculum to the assessment in the teaching of geography is of fundamental importance for understanding learning, and the teacher when working the curriculum may have the opportunity to explore more deeply the role of interactions with other areas of knowledge, and those applied geography has a characteristic analysis of the environment in which the student experiences . By conducting this study on the objective of performing a discussion about curriculum, rating, and school geography during the various stages of construction, we confirm the necessity and importance of doing an analysis on the situation of the current curriculum and assessment practice in geography teaching in a time of many changes in the educational landscape .
\end{abstract}

Keywords: Curriculum, Assessment, teaching geography.

RESUMO: O presente trabalho apresenta como objetivo discutir sobre currículo, avalição, a geografia escolar e os seus desdobramentos na educação básica e a relação da prática curricular vigente com a sistemática de avaliação existente nas instituições de ensino com desdobramentos no processo ensino-aprendizagem. Para a realização deste trabalho foi realizado um estudo bibliográfico acerca de algumas das principais obras relacionado ao tema currículo, avaliação e a geografia escolar. A base para o desenvolvimento deste estudo foram os principais autores que retratavam detalhadamente as principais características de currículo e da avaliação, em especial Maria Adailza Martins de Albuquerque, Tomaz Tadeu da Silva, e Antonio Flavio Barbosa Moreira envolvendo discussões acerca da prática curricular vigente e a relação desta com a avaliação no ensino de geografia. É nas escolas que se vivenciam o currículo de fato, e o ambiente escolar é o lugar que se desenvolve uma pedagogia curricular que apresentam conteúdos geralmente de caráter direcionado a uma concepção pedagógica ou mesmo política. A relação do currículo com a avaliação no ensino de geografia é de fundamental importância para se compreender a aprendizagem, sendo que, o professor ao se trabalhar o currículo pode ter a possibilidade de explorar 
mais profundamente o papel das interações com as outras áreas do conhecimento, e esses aplicados a geografia possui uma característica de analise do meio em que o aluno vivencia. Através da realização deste estudo diante do objetivo de se realizar uma discussão acerca de currículo, avalição, e a geografia escolar, durante as várias etapas de construção, confirmamos a necessidade e a importância de se fazer uma análise sobre a situação do currículo vigente e da prática avaliativa no ensino de geografia, em uma época de tantas transformações no cenário educacional.

\section{Palavras-chave: Currículo, Avaliação, Geografia Escolar.}

RÉSUMÉ: Cet article présente l'objectif de discuter de programmes , évaluation , la géographie de l'école et de ses développements dans l'éducation de base et la relation de la pratique actuelle des programmes à l'examen systématique des établissements d'enseignement existants avec l'évolution du processus d'enseignement-apprentissage . Pour cette étude, une étude de la littérature a été effectuée sur une partie du sujet principal se rapportent au curriculum , d'évaluation et de géographie de l'école œuvres . La base pour l'élaboration de cette étude ont été les principaux auteurs décrivent en détail les principales caractéristiques du programme et de l'évaluation , en particulier Maria Martins Adailza Albuquerque, Tomaz Tadeu da Silva , et Antonio Barbosa Moreira Flavio impliquant des discussions de la pratique du curriculum actuel et la relation avec cette évaluation dans l'enseignement de la géographie . C'est dans les écoles qui connaissent le programme, en fait, et de l'environnement de l'école est le lieu qui développe une pédagogie des programmes qui comportent du contenu de caractère généralement réalisé à une conception pédagogique ou même la politique . La relation du programme de l'évaluation dans l'enseignement de la géographie est d'une importance fondamentale pour la compréhension apprentissage et l'enseignant lorsque l'on travaille le programme peut avoir l'occasion d'explorer plus profondément le rôle des interactions avec d'autres domaines de la connaissance, et ceux géographie appliquée a une analyse de caractéristiques de l'environnement dans lequel les expériences des étudiants . En effectuant cette étude sur l'objectif de réaliser une analyse des programmes, évaluation, et de la géographie de l'école au cours des différentes étapes de la construction, nous confirmons la nécessité et l'importance de faire une analyse sur la situation du programme en cours et la pratique de l'évaluation dans l'enseignement de la géographie dans un temps de nombreux changements dans le paysage éducatif .

Mots-clés: Curriculum , l'évaluation , l'école de géographie.

\section{INTRODUCTION}

This paper presents the objective of discussing the curriculum, the rating, the school geography and its developments in basic education and the relationship of the current curriculum practice with the systematic review of existing in educational institutions with developments in the teaching-learning process in schools, and reflections on education of the student and their profile in today's society. 
The work in geography education requires a curriculum that fosters a "space look" to highlight the problems that occur in the world and a critical look at the phenomena occurring at the present time, ie, a curriculum that comtemple a citizen geography and to provide the student instruments that fosters a critical eye and be talking in school geography, an assessment that comtemple a curriculum with emphasis in geographic space, ie, an evaluative practice through a curriculum that provides meaningful learning and knowledge building.

Over the years, in the case of Brazil, major investments were made in education and also major reforms, both of school structures and curricula and pedagogical ideologies, and the curriculum had to adapt to these changes taking the role of a teacher prominent role to these changes with the increasing need to exercise an appropriate work practices ace new curriculum and new ideological concepts that reflect on teaching and evaluation system in geography.

The changes in the sphere of society require a resume and a proper evaluation practices to the new realities that characterize the organization of society, involving the need to adapt the new curricular practices that exist in actuality linked, in most cases, the exercise of citizenship, especially in terms of knowledge and skills required for the renewal functions of the national labor market.

Knowledge is a reflection of the existing curriculum in a given society, ie, featuring the culture of a people, a nation or a social group and this is nothing more than a tool to facilitate learning, and accordingly Moreira says :

The curriculum is a significant tool used by different companies to develop both the processes of conservation, transformation and renewal of the historically accumulated knowledge as how to socialize children and youths by values regarded as desirable. Given the importance of these processes, the discussion around the curriculum is increasingly taking place in the pedagogical knowledge. (1997, p.11)

The curriculum and assessment on the context of school geography should make this relationship with the professional activity, ie, a meaning of content worked within an existing curriculum through practice and teaching of geography teaching can make a work with their students about the importance of geography and its applications in everyday life. 
The educational landscape is a reflection of the changing curriculum that makes the teacher's job fits the new realities experienced in schools. As a result the curriculum is an activity that requires teacher knowledge and skills in various fields, besides requiring skills and attitudes to facilitate student learning.

\section{MATERIALS AND METHODS}

For this study, a literature study was conducted on some of the major topic related to curriculum, assessment and school geography works. The basis for the development of this study were the main authors portray in detail the main features of curriculum and assessment, in particular Maria Martins Adailza Albuquerque, Tomaz Tadeu da Silva, and Antonio Flavio Barbosa Moreira involving discussions of current curricular practice and the relationship of this with the assessment in the teaching of geography.

Some authors highlight articles and books that mention about the curriculum and teaching of geography and serve as reference for this thematic study in question and in particular the work of the professional training of geography Callai Helena (2013) and the book geography and teaching practices Lana Cavalcanti de Souza (2002).

As a result, there has been an extensive study on the subject in question and a comparison of view of different authors on curriculum, assessment and school geography involving several questions and discussions about the various conceptions of curriculum and its developments in geography.

The theoretical research was used as a method of inquiry with reflective approach on the facts and phenomena occurring in the context of curriculum and assessment in present day, performing the analysis on the theoretical discussion dealing with curriculum, assessment and school geography. The bibliographic research aimed to analyze the current situation of the curriculum and its relationship with the systematic evaluation of school geography and also provide general information about the topic in question.

The analysis was carried out through research, reading and interpretation of texts of the authors surveyed. Sposito (2004) states that there are some necessary to interpret a text care because, given the subject matter under examination concerning knowledge may face in different situations that lead us to situations of interpretation so 
that we know what the best type of research approach, and the method is directly related to the interpretation of texts because of the large amount of published works.

Being a predominantly qualitative approach, concerned with understanding and meaningful interpretation of the phenomena occurring through analysis of the various conceptions of curriculum, assessment and developments in the school geography, taking into account the reflections of these in the current prevailing system of education, with reasoning so well that contributes to knowledge.

\section{A BRIEF DISCUSSION ON THE CURRICULUM}

The curriculum reflects the school geography in a discussion ranging from the design of curriculum theory, passing the theoretical currents of thought of the present day. In the early twentieth century appearance of the first studies on the curriculum, for example, traditional theories. More to come forward ace critical theories of the curriculum, postmodernism and poststructuralist critique of the curriculum. This whole context of discussing the curriculum reflects the current status of geography in school, ie, the geography that is taught through an educational practice that reflects the current conception of curriculum theory.

There is a great debate among the various authors on what could be the curriculum of fact, and the answer to that is in the very conception of this word, ie, the curriculum that is characterized among other things by being an object, element analysis and continuous construction. This first appeared as an object of study in 1920 in the United States because of the close connection with the process of industrialization and immigration movements that intensified the massification of schooling.

From then begin early discussions about the curriculum in schools, with several questions among them that makes questioning about what kind of curriculum, teaching that it teaches by teachers and what kind of customer that is doing curriculum. The answer to all this is the society itself and the manner in which it is organized, ie the citizen society that lives and what this social context, all these elements directly influence the curriculum question. As Silva says:

The central question that serves as the backdrop for any theory of the curriculum is to know what knowledge should be taught. A more synthetic way the central question is what is it? To answer this question, different theories can resort to 
discussions about human nature, about the nature of learning or about the nature of knowledge, culture and society. (2003, p.14)

Curriculum is knowledge, reflect the society in aspects of life in social groups. Human nature, culture and society represent the curriculum in people's lives, and for this there is always a selection criterion, ie, the view that knowledge which constitute by constant construction on what should be taught and what should not be taught, and possible contents to be disposed of in accordance with the reality of society.

Another aspect to be highlighted within the curriculum is the identity, and this refers to what kind of curriculum identifies with each society and that society identifies with certain types of curriculum, or a curriculum involved in what we are, what we become our identity and our subjectivity. Also worth noting the power, since select is a matter of power and privilege one kind of knowledge is a matter of power, this element bound to choose and the way you show the face of who dominates and who is dominated.

Teachers have always been involved in curriculum word, without even knowing the name itself, the use of this happens daily in educational institutions through the selection of subjects, and the organization of content, ie, represents an element of adaptation or reformulation Because of the need to recast the content and disciplines in schools.

During the twentieth century, the shift from traditional theories of curriculum for critical theories, there were important advances on the role of the curriculum in schools, because, in traditional theories they had to focus on forms of organization and curriculum design, since the theories critical start into question the assumptions of the present social and educational arrangements, ie, a curriculum focused on current social conflicts and injustices of society in which they live, as Silva says:

Critical theories suspicious of the status quo, blaming him for the inequalities and social injustices, traditional theories were theories of acceptance, adjustment and adaptation. Critical theories are theories of distrust, questioning and radical transformation. For critical theories is important not to develop techniques for making the curriculum, but to develop concepts that allow us to understand what the curriculum is. (2003, p.30)

The curriculum in critical design plays in shaping people's opinions of the character highlighted, ie, a curriculum that seeks to stimulate critical thinking people. By spending the last century, the discussion about the role of the curriculum in schools 
pervaded the opinion of many authors, who somehow put criticized the way the curriculum that contributed to inequalities and social injustices. These questions call into question the status of traditional curriculum and behind the scene will resume the discussion on the point of view of social inclusion.

\section{CURRICULUM, CULTURE AND SOCIAL STRUCTURE}

The existing social structure today defines the concept of curriculum in educational institutions. The school operates ideologically through your resume, be a more direct way using materials vulnerable to thoughts put on the structures of society as social studies, history, geography, either through a more indirect way more technical disciplines with science and mathematics.

But it is important to note that within this group of subjects ideology can act in a discriminatory way by virtue of the lean people will subordinate submission and obedience classes, while the people of the ruling classes learn to command and control, thus, becomes necessary discussion of the curriculum as a means of social inclusion that helps the student to act as critical citizens of society in which he lives.

Importantly, the educational institutions have characteristics resulting from the capitalist economy, or more precisely the capitalist workplace, so we have a curriculum geared to the interests of the labor market and the economy that values the accumulation of capital. This reflects directly on jobs, vocational education focused on the type of that particular company needs, ie the curriculum built to train skilled labor in certain functions work.

The curriculum reflects the culture of the society, because of that, the culture and social status and value that characterizes the culture of the ruling classes, with their tastes values, customs, habits, ways of behaving, acting, etc.. And in this respect we can classify as culture capital, where that this can be seen in works of art, plays, or can be incorporated and internalized in people's lives directly reflecting on ways to develop the curriculum. On development of the curriculum in society Silva says:

It is through the relationship between knowledge, power and identity issues that the company earn its place in curriculum theory. The course text here understood broadly, courseware, and para book, oral lessons, the official curriculum guidelines, school rituals, festive and commemorative dates, is filled with narratives of society. (2003, p.101) 
In school the curriculum is based on the dominant culture, represented as an expression of the dominant language, and is spread through dominant cultural code, and there is a building that has recognized its cultural capital, since the dominated class has devalued its local culture, and with this, complete the cycle of cultural reproduction through because of this play there is the maintenance of social class through time.

The curriculum provides an opportunity for analysis of what is being worked on by teachers, ie, a reflection and a place where teachers and learners have the opportunity to examine, in a renewed way, those meanings of everyday life have become accustomed to see how data and natural, or is seen as a local expertise and experience of the mark. There is a close relationship between the curriculum and the daily routine of people's lives, whether in their way of life and their culture, is in fact an ongoing activity that builds and rebuilds and such activity is that the curriculum should be understood, not limited to school life, but our life through a whole context and social context.

In the field of curriculum theory, there is a structural relationship between the economy and education and between economy and culture, or society through the context in which they live through their organization, and the sum of these factors directly influence the formation of the curriculum, as Silva said: "There is a link between social reproduction, more specifically there is a clear connection between the way the economy is organized and how the curriculum is organized" (2003, p.45).

In fact, one can say that the curriculum is mediated by human action, which builds knowledge through the curriculum, this element which is built in the school entity that represents a producer of knowledge, especially the so-called technical knowledge, as mentioned Silva:

The "technical knowledge" relates directly to the structure and functioning of capitalist society, since it is relevant to the knowledge economy and production. Obviously this production occurs mainly in higher levels of education, ie university. Insofar as the requirements for entry into university curricula pressure of other educational levels, these curricula reflect the same emphasis on technical knowledge (2003, p.48).

And the technical knowledge ends up being viewed as a knowledge of prestige, compared to other kinds of knowledge, such as, for example, the aesthetic and artistic knowledge. And all this is directly related to power, with the basic question the connection, production and distribution and consumption of materials, economic 
resources and on the other hand, the production, distribution and consumption of symbolic resources such as culture, knowledge, education and curriculum.

The influence of power is the central issue of the discussion about the curriculum, ie, there is a hierarchy in the curricular issue that govern life in society influencing the way of life of people, being a form of knowledge transmission through a hierarchy, or words, knowledge alienated taxes to the interests of society, with direct impacts on the way of thinking of this in relation to the various problems faced in everyday life.

\section{SCHOOL CURRICULUM AND}

It is in schools that experience the curriculum in fact, and the school environment is the place that develops a curriculum pedagogy that feature content of character generally directed to an instructional design or even politics. The curriculum and schools should be places where students have a chance to exercise the skills of participation and discussion of questions of social life, as Silva says: "There is a need to build a space where the longings, desires and the thoughts of students and students can be heard and carefully considered "(2003, p.55).

Given this scenario is questioned about what to teach, and the answer to this may be in itself lecture'posture front of the reality in which he lives, or how to work with content students learn to listen to them, and know what to consider really should be working.

There are many criticisms that involve the issue of curriculum in schools among them that the concept of banking education of Paulo Freire, characterized by being a vision that has knowledge in a series of transformations that are transferred from the teacher to a student as if it were a transfer bank, ie, information is deposited and then derive them at test time.

In the school curriculum should be the subject of intense discussion among teachers, and how to work with them so that he knows how to build your knowledge and not just being mere information repositories and the student must attend classes in an active way and not being passive in education schools, but presenting a posture of forward action in the realities that society experiences.

Working with the curriculum in schools can be done in a way in which the teacher seeks the experience of students "significant issues" that can constitute the programmatic content of curricula in schools involving the various types of education. Culture is an essential content when working the curriculum in schools, and the choice 
of curriculum should be borne in mind popular culture or the next crop, in all reality involving the student and enhances their roots and traditions are characterized in fundamental knowledge for the learning of people's lives.

The company builds your knowledge and applying this to the curriculum, should lead to interventions that prevent knowledge society the reality of schools is adequate, involving the selection, organization, delivery and evaluation of knowledge in educational institutions. The construction of the curriculum in schools can not be restricted only to the division of disciplines or subjects, but in organized knowledge in related areas and that there is a relationship between these areas. Becomes interesting to see the curriculum in a critical manner, taking into account the role of the school in the cultural and social reproduction process and the curriculum is central Papal this process.

\section{ASSESSMENT IN GEOGRAPHY AND THE CURRICULUM}

The curriculum is expressed through the dominant pedagogy in each place where it is worked in each state and in each region and through the teaching practice and the way that the curriculum is worked in educational institutions to directly reflects a systematic review of the resulting practice current curriculum. Make an assessment is not simple to do, so there is a need to make a curriculum planning to thereby know how to assess, evaluate why and when to evaluate according to the existing curriculum. In geographical science curriculum and evaluative practice underwent changes over the years because of the transformations and changes on conceptions of teaching.

Teaching geography nowadays are faced with a time of enormous changes, new technologies are launched in new methodologies appear school environment to improve the quality of teaching and, in turn, new forms curriculum practices and learning assessments appear to modify systematically used, and this is in accordance with the existing curriculum.

Because of these changes in geographical science curriculum design process and evaluation of learning is something beyond what you imagined before. There is a need to transform the curriculum and evaluative act in a way to contribute to the cognitive development of students, and for that a good curriculum planning by the teacher contributes to the improvement of assessment in teaching geography. Actually represents a selection and organization, as stated by Moreira, curriculum shall mean the set of experiences to be lived and observed by the student under the guidance of the 
school. Are the central questions of selecting learning experiences to be offered in educational institutions, to organize them as relating them to the interests and development of the student. (1997, p.12)

And there is much discussion as to relate the curriculum to the planning and evaluation practices, and constructivist theory can help the teacher this question, because of learning reflect the result of the construction of knowledge. When talking about knowledge and learning these are the result mainly of the theories of the genetic epistemology of Jean Piaget and socio-historical research of Lev Vygotsky, which assumes that man is not born knowing everything and does not come into the world so clever, but it is not taxable under the influence of the medium, ie, it responds to external stimuli acting on them to build and organize your own knowledge, a more elaborate way.

As the geographical science itself studies the interactions of man near the middle, nothing fairer than working in evaluative practice and discussion of the geography curriculum topics that are relevant and in accordance with the reality of students. There are several research involving the teaching of geography in schools and curriculum, but when we analyze these, we realize there is always the challenge of integration between theory and practice, and the use of everyday student. Are certainly far from being a reality in our schools and we know that the reasons are varied. What we see, today, is a pedagogical practice and curriculum design that has occurred since the 1980 s and 1990s.

The relationship of the curriculum to the assessment in the teaching of geography is of fundamental importance for understanding learning, and the teacher when working the curriculum may have the opportunity to explore more deeply the role of interactions with other areas of knowledge, and those applied geography has a characteristic analysis of the environment in which the student experiences. Individuals learn not just exploring the environment, but also dialogue, receiving instructions, seeing what others do and listening to what they say and geography in the middle is a clear form of teaching, on a daily, observation of landscapes, problems environment in cities, etc..

When curriculum and assessment are committed to learning, it is not more a sacrifice for teachers and students, because the agents think of the process and participate in it directly and effectively. Thus, we are building a more concrete and democratic education and for helping with student learning. To Rabelo (1998, p.11), 
"review is essential in all human activity and therefore any proposal for education." Despite many changes experienced we still reigning in the school curriculum and assessment as a measure, classification, etc. value judgment. Most often, the act of evaluation is seen as a time of punishment and choice that should be applied to the students and for most students and teachers just comes down to quantity and not quality, without worrying about the sense critical and knowledge building.

Evaluation often is used as a 'weapon' against the student, a way of threatening and arresting the student classes. When this happens, the student shall be afraid of the review, afraid to ask questions and to show you do not know. [...] The distance between teacher and student is getting bigger and there is no room for dialogue. (MELCHIOR, 2004, p. 30).

We must break the distance between teacher and student, and bring the curriculum and geography closer to this and break the molds of the archaic teaching. The curriculum and learning assessment, with a view to a construction continues, should be placed as a means for teaching and learning that is truly effective.

Stefanello (2008) states that for geography perception is not only relevant, but also cognition, which is the basis of geographical studies, according to the perception of reality and the goal you want to achieve and that knowing is to build or rebuild object of knowledge in order to learn the mechanism of this construction. Therefore cognition is a process and analysis of the school curriculum should be part of it.

The choice of curriculum and use of students' prior knowledge can be diagnosed more coverage by teachers if other techniques are used as diagnostic research, interaction in groups, for example, ie, it is up to each teacher of geography choose how more appropriate to work with the curriculum and the assessment practice in geography, taking into account the learning of their students.

New developments arise, new situations also experienced a new reality, was the transformation of the internet and digital technology all reflect the curriculum and learning assessment. And the systematic evaluation criteria should be used in accordance with the curriculum, discussion of objectives, difficulties of diagnosis and definition of instruments, etc.

Piaget, mentioned in his works the 1st, about the importance of the students work together and discuss the contents of disciplines, requiring each participant to explain their ideas and options and thus helping each to understand other points of view and reflect more consciously about the activities, from then, can be a starting point for 
an evaluation and curriculum practice more just in the classroom taking into consideration the students' participatory action.

Within the scenario of geography teaching, discussing many things about the curriculum design and the systematic evaluation of learning in recent years. The simple act of making a choice curriculum and evaluation process should be done with great respect and responsibility to the student. Also in this context, it is worth to point out that review should not only be measured, but perceive a political philosophy and curriculum design that this universe sends us. We should rethink the evaluation methods according to the curriculum so that they have exceeded their limits in view of the introduction of new technologies and a new moment experienced in the educational context. However, it is also worth pointing out that curriculum and assessment is not only a question related to teachers, but the school as a whole.

In the process of teaching and learning assessment in geography, according to the existing curriculum all teachers should have in mind what is to assess a student, knowing that this presents difficulties to learn certain content and how a review can mess with this sentiment, if used incorrectly.

To evaluate curriculum content should not be based on exclusion but inclusion of the learner, always thinking that human being as a great potential for future big deeds. Transforming values and create new spatial concepts can, why not be the main objective of the choice of curriculum and assessment.

When talking about a discipline that addresses the reality of students, for example, the geography, the process of curriculum choice and assessment can occur in various forms and the use of varied instruments in accordance with the various concepts and theoretical positions methodological each teacher.

As a result, it is not enough to say what is or should be considered a fan of practical changes, it is shown that during the curriculum planning process of teaching and learning in geography, in class and at the time of evaluation, ie, throughout the process and not just at a specific moment, but taking into account a whole period.

When we mentioned that the curriculum and assessment in geography as it relates to student learning, we are remitted to think about the effectiveness of the teaching process. In this sense, educators in the field of geography need to be mindful that the concepts put to students are not mere definitions or descriptions of events, it is necessary that the concepts taught are related to the objective world, with the daily lives of these students. For if there is no learning, there is nothing to be evaluated, ie, the 
evaluation method directly depends on the education provided by institutions and the way the teacher explains the issues.

Thus, evaluative and curricular practice we know today is the inheritor of these past periods, which happened the assertion of bourgeois society, marked by exclusion and marginalization of large parts of society, ie, a practice which is not directed to the inclusion social. Therefore, consolidated in our schools practice tests and exams as a resource to classify learners by selecting them and treating them differently and in many cases teachers only concerned with numbers, concerned with the principles of bourgeois individuality and competitiveness. Luckesi mentions that:

Today we apply instruments of dubious quality: corrected proofs and count the dots to conclude whether the student will pass or fail. The process is designed so that some students are included and others excluded. From a pedagogical point of political view, is an undemocratic and authoritarian tradition, because it is centered in the person of the teacher and the education system, not in the learner (2006, p.18).

The controversy surrounding the discussion of what really is the curriculum and assessment in education is quite large. Although much has already been discussed, the issue is far from a consensus approach. The evaluation method and choice of curriculum should be an inclusive process of human existence, which implies a critical reflection on their practice in order to capture their advances their resistance, their difficulties and enable decision making. The same must accompany the student in the process of growth and be seen as a facilitator of this process tool, not as an inhibitor of the same, marking people negatively for the rest of their lives.

From this perspective, working with the curriculum and know how to evaluate cease to mean making a judgment about student learning, to serve as yet able to reveal what it already knows the path she took to attain knowledge demonstrated, the process of building knowledge and may exacerbate, reveal its advancement opportunities and needs to get over that.

The evaluative and curricular practice provides a moment of change, progress, advancement, finally learning she is procedural, continuous, participatory diagnostic and investigative. The same part of the educational function of the learning process. Evaluates to diagnose advances and barriers to intervene, act, problematize and redefine the directions and routes to be followed. In this context, Hoffmann says: 
[...] The evaluation process to which I refer is an investigative method that dispenses with traditional, coercive and forceful correction. Rather assumes that the teacher is increasingly alert curricular concepts and lean comprehensively on all manifestations of the student taking into account the skills and abilities (1991, p.79).

In addition to the curriculum and assessment serves learning is essential that teachers know each of their students and their needs, for only thus can think of different alternatives so that all students achieve the goals. Thus, to evaluate one must go beyond the measure using more complex indicators and evidence of competence, given that there is no assessment for rating, but to base a decision. In this context, Hoffmann emphasizes the importance of planning as well as the diversification of evaluation instruments: If clear guidelines are given, the teacher makes his way thanks to his creativity. These features can be well diversified, participatory, democratic, relevant, meaningful and tightly constructed. Today we use the term to "portfolios" of proposal evaluation. Diversifying the instruments can cover all facets of performance of a student (1991, p.94).

Therefore, the reconstruction and evaluation of curricular practical training assumes teachers with critical, able to broaden their horizon of understanding and recognition of the need for constant training and a willingness to be subject of change and build something different.

FINAL

By conducting this study on the objective of performing a discussion of curriculum, rating, and school geography during the various stages of construction, we confirm the necessity and importance of doing an analysis on the situation of the current curriculum and assessment practice in geography teaching in a time of many changes in the educational landscape as we experience today in an intense process of globalization there is a need for further work on this issue because we are experiencing a scenario of learning with intense transformations.

However, we identified before the preparation of this paper and analysis of the opinion of the authors found that the educational scenario lacks a curriculum that comtemple a citizen geography and to provide the student with tools that fosters a critical and participatory look worked before the current issues in education geography, ie, it is a field that needs further deepening of studies and interpretations of what it 
means to curriculum and assessment practice of geography in schools, which consequently makes this study is set as a look at the reality experienced in teaching in the institutions that form the student citizen.

The intense changes occurring in the education scenario require a resume and a proper evaluation practices to the new realities, ie, a curriculum that contributes to the new social demands and to provide the expertise and knowledge that is presented by a continuous build on what is should be taught in the classroom. The current curriculum and assessment practice in schools should provide students with the exercise of powers and abilities, helping the student to fighting the problems of everyday life, to understand the reality in which society lives.

The contribution of this study lies in the fact that relevant point to be discussed in future studies that focus on the theme of the situation of curriculum and assessment in the teaching of geography, focusing mainly on its relationship with students' learning in schools issues.

And finally, the work presented in the discussions before and performed together with the theoretical questions about the need for changes in the way teachers understand about the topic and review the current curriculum, so there is an understanding of the importance of the work of the two themes in educational institutions and to provide improved professional practice and teaching of geography.

\section{REFERENCES:}

ALBUQUERQUE, Maria Martins Adailza; FERREIRA, JA Training, Research and Educational Practice: Curriculum Reform in question. Ed Media Graphic, João Pessoa, PB: 2013.

CALLAI, Helena Copetti. The professional training of geography: the teacher. Ed, Unijuí, Ijuí-Sc 2013.

CAVALCANTI, Lana de Souza. Geography and teaching practices. Alternative Ed, Goiânia: 2002.

HOFFMANN, J. A review, myth and challenge: a constructivist perspective. 29th ed. Port: mediation, 2000.

. Review the service of the student and not against it. Young World, Jolly Harbour, V.12, No. 36, April, 1992.

1991.

Review mediating Education and reality. Ed Jolly Harbour, UFRGS, 
LUCKESI, CC Evaluation of school learning. 17th ed. Sao Paulo: Cortez, 2006.

MOREIRA, Antonio Flavio Barbosa. Curriculum: current issues. Campinas-SP: Papyrus, 1997.

Piaget, Jean. The symbol formation in child imitation, play and dream, imitation and representation. Rio de Janeiro: LTC, 1990.

A-Balancing of Cognitive Structures Central Problem of Development. Zahar Editores, Rio de Janeiro, 1976.

RABELO, EH rating: new times, new practices. 5. Ed. Petropolis: Voices, 1998.

SILVA, Tomaz Tadeu da. Identity documents: an introduction to theories of curriculum. 2nd ed. Belo Horizonte: Authentic, 2003.

SPOSITO, E. S. Geography and Philosophy: contribution to the teaching of geographical thought. Sao Paulo: UNESP, 2004.

STEFANELLO, A. C. Teaching and assessment of learning in geography teaching. Curitiba: IBPEX, 2008.

VYGOTSKY, L. S. Thought and Language. Trad. M. Resende, São Paulo: Martins fintes, 1987.

Interaction between learning and development. In The social formation of mind. London: Routledge, 1998.

\section{Language development and}

learning. London: Icon, 1989 